\title{
Study on Lipid Profile of Type 2 Diabetes Mellitus Patients Attending Medical College \& Hospital
}

\author{
Mamta Singh ${ }^{1}$, lla Bhattacharjee ${ }^{2}$ \\ ${ }^{1}$ Senior Resident, Department of Biochemistry, AlIMS-Patna, Patna, ${ }^{2}$ Retd. Professor and Head, Department of Biochemistry, MGMMCH, Kishanganj.
}

\section{Abstract}

Background: Diabetes mellitus is major public health problem. It is associated with metabolic abnormalities and long term complications. Subjects and Methods: The present study included 150 cases of diabetes. Detailed history, clinical examination and assessment of glycemic control and serum lipid profile was done. Results: The mean total cholesterol level was $197.4 \pm 14.2 \mathrm{mg} / \mathrm{dl}$, triglyceride level was $156.8 \pm 21.7$ $\mathrm{mg} / \mathrm{dl}$, HDL level was $42.3 \pm 5.7 \mathrm{mg} / \mathrm{dl}$, LDL level was $121.1 \pm 9.3 \mathrm{mg} / \mathrm{dl}$, VLDL level was $34.2 \pm 6.5 \mathrm{mg} / \mathrm{dl} \& \mathrm{LDL} / \mathrm{HDL} \mathrm{ratio}$ was $2.81 \pm$ 0.29. Conclusion: Serum lipid profile is deranged in diabetic patients.

Keywords: Descriptive study, Lipid Profile, Type 2 Diabetes mellitus.

Corresponding Author: Dr. Mamta Singh, Senior Resident, Department of Biochemistry, AIIMS-Patna, Patna.

Received: February 2019

Accepted: February 2019

\section{Introduction}

The prevalence of Diabetes mellitus is continuously increasing worldwide and India contribute to it significant proportion. ${ }^{[1]}$ It has been estimated by International Diabetes Federation that by the year 2025, there will be 69.9 million diabetics in India. ${ }^{[2]}$ Diabetes is a multisystem disorder with defects in insulin secretion, insulin action, or both. $^{[3]}$ This results in damage to blood vessels, cardiovascular system, brain, kidneys, eyes etc. ${ }^{[4]}$

It also affects metabolic processes. Dyslipidemia and alterations in various components of serum lipid is one of the important changes seen. These derangements are significantly associated with atherosclerosis and resultant complications. ${ }^{[5]}$

Hence, the present study was conducted to assess serum lipid profile in type 2 diabetic patients.

\section{Aims and objectives}

The present study was conducted to assess the serum lipid profile in Type 2 diabetic patients attending a medical college hospital.

\section{Subjects and Methods}

The present study was cross sectional in nature conducted at the department of Biochemistry at a medical college hospital. Type 2 diabetes mellitus patients reporting to the hospital above the age of 20 years were included in the study. Those patients with concomitant diseases affecting serum lipid profile like chronic liver disease \& hypothyroidism or those taking medicines known to alter the same like oral contraceptive pills, steroids and diuretics were excluded. A total of 150 patients reporting to the hospital and fulfilling selection criteria were studied.

Informed consent was taken from the study subjects. Detailed history was taken from each patient and thorough clinical examination was done. The serum was separated immediately after obtaining the blood sample (overnight fasting) by using centrifugation for 10 minutes. Serum samples were collected for FBS in tubes containing sodium fluoride and ammonium oxalate and for lipid profile $3 \mathrm{ml}$ venous blood was drawn aseptically in plain tubes. Serum glucose was determined by GOD-POD end point (coefficient variation of $4.84 \%$ ). Lipid Profile like Total Cholesterol (TC) was measured by CHOD-POD end point method with a co-efficient variation of $2.91 \%$, Triglycerides (TG) by the GPO-PAP end point method with co-efficient variation of $2.78 \%$ and High Density Lipoprotein (HDL) and Low Density Lipoprotein (LDL) by Friedwald's formula with co-efficient variation of $1.5 \%$ and $2.3 \%$ respectively.

National Cholesterol Education Programme (NCEP) Adult Treatment Panel III (ATP III) guidelines were followed for diagnosis of lipid abnormalities. Hypercholesterolemia was defined as TC > $200 \mathrm{mg} / \mathrm{dl}$, high LDL-C as > $100 \mathrm{mg} / \mathrm{dl}$, hypertriglyceridemia as TAG $>150 \mathrm{mg} / \mathrm{dl}$ and low HDL-C as value $<40 \mathrm{mg} / \mathrm{dl} .{ }^{[6]}$ The data obtained were entered in MS Excel. Data were expressed as mean \pm SD and $\mathrm{p}<0.05$ was considered to be statistically significant.

\section{Results}

A total of 150 patients of Type 2 Diabetes were included in 
the present study. Mean age of the study subjects was 48.7 \pm 12.3 years. $58.7 \%$ were males and the remaining $41.3 \%$ females. Mean duration of diabetes mellitus was $4.2 \pm 3.9$ years. Table-1 shows the glycemic control among diabetic patients. Mean HbA1C was $8.37+1.9$. Mean FBS was $147.2+48.6 \mathrm{mg} / \mathrm{dl}$ and mean PPBS was $213.5+77.6$ $\mathrm{mg} / \mathrm{dl}$.

Table 1: showing glycemic control among diabetic patients

\begin{tabular}{|l|l|}
\hline Parameter & Mean \pm SD \\
\hline HbA1C & $8.37+1.9$ \\
\hline FBS & $147.2+48.6 \mathrm{mg} / \mathrm{dl}$ \\
\hline PPBS & $213.5+77.6 \mathrm{mg} / \mathrm{dl}$ \\
\hline
\end{tabular}

[Table 2] shows the serum lipid profile of diabetic patients. The mean total cholesterol level was $197.4 \pm 14.2 \mathrm{mg} / \mathrm{dl}$, triglyceride level was $156.8 \pm 21.7 \mathrm{mg} / \mathrm{dl}$, HDL level was $42.3 \pm 5.7 \mathrm{mg} / \mathrm{dl}$, LDL level was $121.1 \pm 9.3 \mathrm{mg} / \mathrm{dl}$, VLDL level was $34.2 \pm 6.5 \mathrm{mg} / \mathrm{dl} \& \mathrm{LDL} / \mathrm{HDL}$ ratio was $2.81 \pm$ 0.29 .

\begin{tabular}{|l|l|}
\hline Table 2: showing serum lipid profile of diabetic patients \\
\hline Parameter & Mean \pm SD \\
\hline Total cholesterol & $197.4 \pm 14.2 \mathrm{mg} / \mathrm{dl}$ \\
\hline Serum triglyceride & $156.8 \pm 21.7 \mathrm{mg} / \mathrm{dl}$ \\
\hline HDL & $42.3 \pm 5.7 \mathrm{mg} / \mathrm{dl}$ \\
\hline LDL & $121.1 \pm 9.3 \mathrm{mg} / \mathrm{dl}$ \\
\hline VLDL & $34.2 \pm 6.5 \mathrm{mg} / \mathrm{dl}$ \\
\hline LDL / HDL ratio & $2.81 \pm 0.29$ \\
\hline
\end{tabular}

\section{Discussion}

A total of 150 patients suffering from type 2 diabetes mellitus were studied to find the serum lipid profile. Mean age of the study subjects was $48.7 \pm 12.3$ years. $58.7 \%$ were males. Mean duration of diabetes mellitus was $4.2 \pm 3.9$ years.

Singh et al found mean age to be $50.3 \pm 11.8$ years. ${ }^{[6]}$ Sultania et al found that mean age in both diabetic and control patients was $50.3 \pm 11.90$ years and age range was 25-85 years. Both groups were well matched for age and sex distribution. ${ }^{[7]}$ Jaya et al reported that out of the diabetic patients, $51 \%$ were males and $49 \%$ were females. In the controls, there were $52.4 \%$ males and $47.6 \%$ females. ${ }^{[8]}$ Kolhar et al found that $56 \%$ were males and $44 \%$ were females. The mean age of patients was $54.9+7.6$ years. Mean duration of diabetes mellitus was $5.13+4.5$ years. ${ }^{[9]}$ Gamit et al observed that mean age of participants was $48.93 \pm 12.1$ years. ${ }^{[10]}$

In the present study, mean $\mathrm{HbA} 1 \mathrm{C}$ was $8.37+1.9$. Mean FBS was $147.2+48.6 \mathrm{mg} / \mathrm{dl}$ and mean PPBS was $213.5+$ $77.6 \mathrm{mg} / \mathrm{dl}$. Singh et al found that mean fasting blood glucose level was $135.1 \pm 27.4 \mathrm{mg} / \mathrm{dl} .{ }^{[6]}$ Kolhar et al found that mean $\mathrm{HbA} 1 \mathrm{C}$ was $9.03+2.1$. Mean FBS was $169.6+$ $54.7 \mathrm{mg} / \mathrm{dl}$ and mean PPBS was $278.9+91.3 \mathrm{mg} / \mathrm{dl}^{[9]}$ Gamit et al observed that mean FBS of study participants was $188.76 \pm 54.63 \mathrm{mg} / \mathrm{dl} .^{[10]}$

It was seen in the present study that the mean total cholesterol level was $197.4 \pm 14.2 \mathrm{mg} / \mathrm{dl}$, triglyceride level was $156.8 \pm 21.7 \mathrm{mg} / \mathrm{dl}$, HDL level was $42.3 \pm 5.7 \mathrm{mg} / \mathrm{dl}$,
LDL level was $121.1 \pm 9.3 \mathrm{mg} / \mathrm{dl}$, VLDL level was $34.2 \pm$ $6.5 \mathrm{mg} / \mathrm{dl} \& \mathrm{LDL} / \mathrm{HDL}$ ratio was $2.81 \pm 0.29$. Singh et al reported that the mean total cholesterol level was 203.9 $\pm 15.8 \mathrm{mg} / \mathrm{dl}$, triglyceride level was $151.1 \pm 17.7 \mathrm{mg} / \mathrm{dl}$, HDL level was $47.7 \pm 6.2 \mathrm{mg} / \mathrm{dl}$, LDL level was $124.4 \pm$ $11.9 \mathrm{mg} / \mathrm{dl}$, VLDL level was $32.3 \pm 7.1 \mathrm{mg} / \mathrm{dl} \& \mathrm{LDL} /$ HDL ratio was $2.63 \pm 0.37 .{ }^{[6]}$ Sultania et al found that there was highly significant difference in mean HDL in diabetic and control patients $(\mathrm{p}<0.0001)$. There was highly significant difference in mean Triglycerides in diabetic and control patients $(\mathrm{p}<0.0001)$. There was no significant correlation found between HbA1c and TC, LDL, HDL, TG. ${ }^{[7]}$ Jaya et al reported that $13.4 \%$ among the males and $11.8 \%$ among the females in the diabetic group had high levels of total cholesterol as against $5.7 \%$ and $4.6 \%$ in males and female controls respectively. High triglyceride levels were observed in the diabetic patients with $40.2 \%$ of the males and $55.5 \%$ of the females. ${ }^{[8]}$ Kolhar et al found that the prevalence of dyslipidaemia was 90\%. The prevalence of dyslipidaemia in males was $91 \%$ whereas the prevalence of dyslipidaemia in female DM patients was $88.6 \% .{ }^{[9]}$ Gamit et al observed that mean triglycerides level was $202.56 \pm 83.45 \mathrm{mg} / \mathrm{dl}$. Borderline high cholesterol (200-239 mg/dl) and high cholesterol ( $\geq 240 \mathrm{mg} / \mathrm{dl})$ level were seen in $17.9 \%$ and $13.6 \%$ subjects respectively. $23.6 \%$ had borderline high triglyceride (150-199 mg/dl) while $41.4 \%$ had high triglyceride (200-249 mg/dl) level. ${ }^{[10]}$ Venkatesh et al found that the mean value of LDL-C, TG and VLDL-C (113.62 $\pm 39.26,163.53 \pm 87.6,32.76 \pm 17.49)$ were higher than the normal range and mean value of HDLC (38 \pm 9.9$)$ was lower than the normal range. ${ }^{[11]}$

The assessment of serum lipid profile indicates that majority of diabetics had high levels of LDL and raised LDL/HDL ratio as also observed by other researchers. Regular assessment of serum lipid in these patients and timely management of abnormalities can be helpful in reducing morbidity and mortality due to this condtion.

\section{Conclusion}

It is concluded from the present study that serum total cholesterol, triglyceride and low density lipoproteins were elevated in diabetic patients and high density lipoprotein was reduced. Hence, annual lipid profile estimation should be done in all diabetics and they should be treated adequately.

\section{References}

1. Ambrish Mithal, Debashish Majhi, M. Shunmugavelu, Pradeep G. Talwarkar, Hardik Vasnawala, Ammar S. Raza. Prevalence of dyslipidemia in adult Indian diabetic patients: A cross sectional study (SOLID). Indian J Endocrinol Metab., 2014 Sep-Oct; 18(5): 642-647.

2. International Diabetes Federation (IDF), 2003. Access to Insulin. A report on the IDF Insulin task Force on Insulin 1994-1997.

3. American Diabetes Association., Diagnosis and classification of Diabetes mellitus. Diabetic care 2005;28 (1):537-542.

4. World Health Organization. Global report on diabetes. World Health Organization; 2016.

5. American Diabetes Association: Management of dyslipidemia in 
adults with diabetes (Position Statement). Diabetes Care 2003; 26 (Suppl. 1):S83-S86.

6. Singh G, Kumar AK. A Study of Lipid Profile in Type 2 Diabetic Punjabi Population. Journal of Exercise Science and Physiotherapy 2012; 8 (1): 7-10.

7. Sultania S, Thakur D, Kulshreshtha M. Study of lipid profile in type 2 diabetes mellitus patients and its correlation with HbA1c. International Journal of Contemporary Medical Research 2017;4(2):437-439.

8. Jaya N, Chowdeswari N. Prevalence of High Lipid Profile in Diabetes Meellitus Patients: A Study in a Tertiary Care Centre. International Journal of Clinical Biochemistry and Research 2016;3(1):120-123.
9. Kolhar U, Priyanka P. Study of serum lipid profile in type 2 diabetes mellitus patients and its association with diabetic nephropathy. Int J Adv Med 2017;4:1513-6.

10. Gamit DN, Mishra A. A lipid profile study amongst the patients of type 2 diabetes mellitus - A cross sectional study. IAIM, 2018; 5(2): 15 .

11. Venkatesh SK, Sudheer KMV, Mohana KT. Lipid profile analysis of type 2 diabetic patients in Bengaluru population, India. Int J Res Med Sci 2018;6:2049-53.

Copyright: (C) the author(s), 2019. It is an open-access article distributed under the terms of the Creative Commons Attribution License (CC BY 4.0), which permits authors to retain ownership of the copyright for their content, and allow anyone to download, reuse, reprint, modify, distribute and/or copy the content as long as the original authors and source are cited.

How to cite this article: Singh M, Bhattacharjee I. Study on Lipid Profile of Type 2 Diabetes Mellitus Patients Attending Medical College \& Hospital. Asian J. Med. Res. 2019;8(1):BC20-BC22.

DOI: dx.doi.org/10.21276/ajmr.2019.8.1.BC7

Source of Support: Nil, Conflict of Interest: None declared. 